\title{
Parent's Involvement in the Program for Developing of Children's Emotional Social Values in Darussalam Kindergarten of Sugihwaras Sidoarjo
}

\author{
Siti Masfufah $1, a^{*}$, Eko Darminto $1, b$, Najlatun Naqiyah $1, c$ \\ ${ }^{1}$ Postgraduate of Basic Education, Surabaya State University, Surabaya, Indonesia \\ a masfufah1812@gmail.com \\ *Corresponding Author \\ Whatsapp Number [ +62 85815812798 ]
}

How to Cite : Masfufah, S., Darminto, E., \& Naqiyah, N (2019). Parent's Involvement in the Program for Developing of Children's Emotional Social Values in Darussalam Kindergarten of Sugihwaras Sidoarjo. International Journal for Educational and Vocational Studies, 1 (3), 157-165.

\section{ARTICLE HISTORY}

Received: 12 June 2019

Revised: 18 July2019

Accepted: 26 July 2019

\section{KEYWORDS}

Parent's Involvement, Emotional Social Value Program, Early Childhood,

\begin{abstract}
This study aims to determine the forms of emotional, social values of children aged 5-6 years and their implementation with a parent engagement program. The subject of research children aged 5-6 years group B in the Sugihwaras kindergarten in Sidoarjo Temple with a total of 7 children and their parents. The research approach used is qualitative data collection techniques through observation, documentation, and interviews and field notes as well as the use of Cresswell's data analysis which is processing data and preparing data for analysis, reading all data, coding data, applying the results of the coding process and finally describe the results of the data during the study. The findings of this study will be tested for truth by using triangulation techniques. The findings of this study indicate the results that the Parental Involvement in the Children's Emotional Social Value Program in TK Darussalam Sugihwaras Sidoarjo Temple is carried out through the social-emotional value program by involving parents in the TK institution. Parental support has benefits and a big contribution to the education of their children. Throughout bonding activities, cooking classes, parenting, curriculum preparation, habituation activities at home, and modeling to develop children's emotional values according to their age stages and abilities. The involvement of parents in children's emotional, social value programs at every school institution should be fully socialized. Given the participation of parents is needed in the child's emotional, social process. Support, appropriate stimulation, and opportunities to explore children can grow and develop good social-emotional values of children.
\end{abstract}

This is an open access article under the CC-BY-SA license.

\section{INTRODUCTION}

Kindergarten Education (TK) is a program unit in early childhood education services (PAUD). Implemented at a non-formal educational institution with a process of learning activities with direct interaction between one student and another, as well as between students and teachers by involving or involving the role of parents using the learning process while playing in the unit program implemented by needs children (Permendiknas. No 137 of 2014 article 1 paragraph 11).

Educators must be able to provide professional services to lay down the knowledge base by the child's development. All the about development in early childhood, all the values of development are very important to be developed, one of which is the value of social-emotional development, which is considered necessary to be considered and instill- ed in children from an early age. As the intended social, emotional development program covers all forms of actualization in the form of learning in the context of early childhood learning with the aim of creating an atmosphere for development and sensitivity in attitudes and social skills and maturity in the development of emotions in the context of the play.

Development of emotional, social values that are instilled from an early age will be able to direct the child's attitude in the ability to interact and socialize both with the family environment or the community in general so that children will be sensitive to the environment in which the child lives. Likewise, in the opinion of Papalia (2014), the foundation in psychosocial development includes children's emotions and early experiences with parents. Children have a need to interact with others. The 
need as a social creature has been actively developed since birth.

Early experiences in children's social-emotional development largely determine children's behavior later on. The many experiences that children have, especially experiences that make children feel happy with what has been gained from previous experiences, will be able to encourage children to look for experiences that are fun like that again in the development of further social abilities. The experiences gained during childhood are considered not only important for children, but also for subsequent development. Tirtayani (2014), states the family is the first and foremost environment for the social-emotional development of preschool-age children. Experience in the family environment will bring good and bad impacts as the first experience that children get in terms of education.

The advantages of TK Darussalam are different from other kindergartens, according to the results of pre-research observations such as in TK AL-Hikam, TK Kusuma Bangsa, TK Kasih Bunda, TK DWP II who are all located in the Subdistrict of Sidoarjo Temple, there are still many parents who drop off and wait for children the children in kindergarten environment until there is also someone in the class because their children are always crying when left by their mother even though TK B is already supposed to be brave and independent. So that when other classmates feel annoyed and less comfortable with the presence of parents who are always waiting for their children while in class. For example, in kindergarten Darussalam, children who are not accompanied by their parents have high independence. Children are able to show a willingness to follow a number of rules when in Keals, play or games, rules of marching, eating rules, and so on.

The superiority shown is that it cannot be separated from the collaboration between parents and kindergarten institutions in terms of parental involvement (the results of preliminary studies), collaboration is only focused on involving parents not collaboration with the community, with the involvement of parents with kindergarten institutions has many positive impacts both for kindergarten institutions and in all aspects of children's development in line with the involvement of parents with programs implemented in the TK Darussalam institutions. In order for parents to know further, that kindergarten education aims to develop all aspects of development both from the ability to develop religious and moral values, cognitive, physical motor, language, social-emotional, and art, and parents understand that the participation of parents includes one of the most important aspects of children's education from an early age.

The development of emotional, social intelligence increasingly needs to be understood, owned, cared for, because by seeing and remembering in real-life conditions and in accordance with the times, at this time it is very complex and many have an unfavorable impact on the development of social and emotional lives of children. There is a lot of real evidence either in school institutions or in the community, about the emotional control of many children at school age who have the courage to challenge their teachers when reminded, and some even dare to hit or use violence when the teacher advises, and children do not want to accept it this is evident from several cases that emerged both from print and electronic media. Things like that happen because the planting in emotional, social education is still not ripe, so the child is not ready and unable to control emotions properly.

\section{METHODS}

The type of research used in this study is a type of qualitative research with a phenomenological perspective approach. Where in phenomenological studies try to prove and look for the "essence" meaning of a phenomenon that has been experienced by several Creswell individuals (2014), this type of research with a qualitative approach emphasizes the analysis of the process of thinking inductively related to the dynamics of the relationship between observed phenomena, and always using Gunawan's scientific logic in Sugiyono (2016).

This study focuses on the study of the participation of parents in social-emotional value development programs in TK Darussalam Sugihwaras. The assessment of problems in this research is a social and dynamic problem. Researchers choose the type of qualitative research with the aim to determine the results and then describe it by searching, collecting, processing, and analyzing the research data. So that clear patterns will be found. This study uses a descriptive pattern, which means that the research seeks to provide a picture and interpret objects according to what is in the results of Best Darmaji's research (2017).

Milles and Huberman (2014) expressed their views on qualitative research as data that appears in the form of words and not a series of numbers. The data is collected in various ways, including observation, interviews, documents, and tape.

The research subjects that the researchers chose in this study were children of group B in Sugihwaras Kindergarten, Candi District, Sidoarjo Regency. With a total sample of 7 children in the B3 group, which consisted of 2 male students while female 5 , then the parents of 7 parents, as well as one principal and two teachers of the B3 group.

In this study, to analyze data using Creswell's (2015) data analysis, which emphasizes that data analysis is an ongoing process that requires continuous reflection of data, asking analytical questions, and writing field notes throughout the study. The next step is to show the results during the research in the form of descriptive, the data from our research are sorted, arranged, elaborated so that the data that has been obtained has meaning. The final steps are interpreting the data or interpreting the entire data so that the results of the study are arranged coherently as an illustration of research that has been done.

Checking the validity of the data to ensure the validity of the data or validating the data, for the examination, the researcher uses data triangulation techniques, namely by 
collecting data from observations of the learning activities undertaken by the teacher with children, interviews with teachers, children and parents.

Triangulation is a method of synthesizing data to its truth by using other data collection methods or various triangulation paradigms. Data that is declared valid through triangulation will give researchers confidence about the validity of the data, so there is no doubt in making conclusions about the research conducted by Bachri (2010).

\section{RESULTS AND DISCUSSION}

\section{Results}

The results of the study describe that the results of the data from the development of children's emotional values at the stage regarding the forms of obeying class rules (activities, rules). The following is one of the results of the researcher interview with informant one on May 17, 2019 (8.30-9.00):

(06.1) : Can we go to school, not wearing uniforms?

"You can't ... because all my friends wear uniforms."

(06.2) : Children already know the school rules?

"I have .. every day the teacher tells the rules, my mother also knows, I can't be crowded when in class ..."

(06.9) : What is the attitude of the children when there is a teacher explaining the lesson?

"We must listen and pay attention."

(06.15): Are there rules that give teachers when we play? "Yes, there is ... we cannot chat with friends and must be willing to wait their turn."

The results of interviews with informants two conducted by researchers on May 18, 2019 (8.00-9.15) are related, showing the forms of obeying the class rules have different results from the previous informants. When researchers try to approach the informant. Seen, he is not afraid and acts Rama like someone who is already known. Below are the results of the researchers' interview with informant 2:

(06.12): Glad that Amira can go to kindergarten in Darussalam?

"Yes ... I'm glad my sister used to go to school here ... I'm happy because there are a lot of toys."

(06.13): Does Amira cry if mama does not accompany you?

"You know ... Mama has never waited for me, said the teacher. If you go to school, it means that you have grown up and can't be whiny."

(06.11): When Amira goes to school, what clothes should we wear?
"Yes, the school uniform, teacher ..."

(06.8): Can we disturb our friends when doing activities?

"You can't ... Teacher every day also says, children when we do activities can not disturb their friends ... Like that"

(06.5): What is our attitude towards friends?

"We must love and must not fight."

Based on the interviews with informants 1 and 2, it can be illustrated that the informant has been able to show forms of obeying the class, although occasionally informants must also be reminded about the rules and regulations so that the informant always remembers and has become accustomed to the existing regulations. To be able to develop social, emotional value in accordance with the indicators of applied poverty.

Data Triangulation Results Forms obey class rules at the stage of understanding the form of rules in class

\begin{tabular}{cl}
\hline No. & Convergence Interpretation \\
\hline 1 & Able to mention the rules as expected even though not as a whole \\
\hline 2 & Know the forms of obeying class rules \\
\hline 3 & $\begin{array}{l}\text { Supporting factors for children to know and want to comply with class } \\
\text { rules is the willingness of children, teachers, parents and the } \\
\text { environment. }\end{array}$
\end{tabular}

Based on the three presentations above, it can be seen that the data tends to be consistent, stating that the informant has developed in line with expectations, in understanding the forms of obeying classroom rules with support from active parents in school programs. So it can be concluded that the overall data of the informants in the stage of understanding the forms of obeying the class rules can be said to be valid.

Triangulation Results Data on social, emotional ability at the stage of implementing rules in the classroom.

\begin{tabular}{cl}
\hline No. & Able to implement regulations that have become habituated \\
\hline 1 & Able to mention the rules as expected even though not as a whole \\
\hline 2 & $\begin{array}{l}\text { Able to implement class rules in accordance with social emotional } \\
\text { development }\end{array}$ \\
\hline 3 & $\begin{array}{l}\text { Active parents in school programs and teachers are able to be one of } \\
\text { the supporting factors of children in implementing classroom rules and } \\
\text { children's willingness and awareness. }\end{array}$ \\
\hline
\end{tabular}

Based on the three presentations above, it can be seen that the data consistently states that all of the informants are able to implement them, from understanding the forms of class rules to how they are implemented. So it can be concluded that the social-emotional data development of informants at the implementation stage is said to be valid. 


\section{Discussion}

In this section is a discussion that aims to describe and analyze with things that will be associated with theories and relevant research results related to social-emotional in obeying classroom rules with active parents in school programs. The purpose of linking research results with the theory is to make it easier to draw conclusions from the results of this study.

According to Rimm Sylvia (2018) states that obeying the rules is an attitude of discipline to direct the child so that he is able to control himself. In addition, so that children are able to carry out activities directedly, in accordance with applicable rules. From the foregoing opinions, it can be seen that the purpose of obeying the rules is to direct the child so that he is able to control himself, can do activities while at school both inside and outside the classroom with direction, and able to learn to live with good, positive, and habitual habits. Beneficial for himself and his environment. So that if at any time there is no supervision from outsiders, then he will consciously always act in accordance with applicable norms and rules.

\section{a. Dress neatly}

In the opinion of Auerbach (2017), that children's emotional, social development skills have the following aspects: begin to show some self-control, be able to tidy up items or toys that have been used in their original place, be able to wear their own clothes neatly, be able to make simple choices, try makes others feel good, and is able to adjust, the level of curiosity increases rapidly, able to enjoy praise, respond to verbal instructions, and be able to distinguish the sexes of girls and boys.

Referring to the above opinion, the ability to dress neatly on the informant began to appear, so that the informant easily knew how to implement it. That the development of emotional, social skills of each informant has developed, reinforced from the results of the interview parents that informants always pay attention to uniforms or clothing that must be worn in certain activities. So neat understanding for informants has become a habit even though informants sometimes have to be reminded and prepared by their parents. The ability of informants to dress neatly is in accordance with their development being able to recognize uniforms that must be worn on certain days and be able to maintain the cleanliness of clothing wherever the child is located and choose clothes that are in accordance with the activities he is doing.

\section{b. Pray before and after carrying out activities}

In the Regulation of the Minister of Education and Culture of the Republic of Indonesia Number 137 of 2014 Concerning the National Standard for Early Childhood Education which states that in a vulnerable age of 5-6 years children are able to pray before and after carrying out activities as an embodiment of the rules and regulations when in class. When children at school there are some rules that must be obeyed, one of them praying before and after carrying out activities, in each activity children are taught to start the activity by always reading prayers both before eating and after eating, starting the activity with basmalah and ending with hamdalah reading, this habituation is done every day so that children also easily apply it when the children are at home.

This is in line with the results of observations on each informant which is also supported by the results of interviews from the teacher, parents are also the informants themselves, parents of informants who say that the informant is clever in reciting prayers together with meaning in addition to being a habit that is in the family when at school children are also used to reciting prayers before and after activities in an orderly manner. If researchers observe from each informant on the achievement of orderly development in prayer is in accordance with the targeted development achievements.

\section{c. Carry out the task to completion}

Hurlock (2016) It is very important in understanding the development process that exists in children from an early age so that the characteristics of the development process owned by each child is able to develop properly. Characteristics of emotional, social development in children aged 5-6 years, has several changes in aspects which include: 1) children are able to accept responsibilities according to age and the role they have, 2) happy with the experience gained, 3) able to complete the tasks given immediately to completion. Carrying out assignments to completion is indeed one of the achievements in the development of emotional, social values in obeying class rules (activities, rules).

Independence in doing their own tasks until completion is still closely related to the child's interest in something. If the child has an interest in something, whether it is an object or food, without being told, the child will immediately take the object or food. Likewise, in doing tasks when the child has grown up with his interests, then the task will automatically be completed. This is in line with the opinion of Hurlock (2016) the characteristics of emotional, social development in children aged 5-6 years, one of which is that children are able to accept responsibilities according to their age and role, capable of completing tasks given immediately until completion. Therefore, in order not to bore children in working on their tasks, it is necessary to think of interesting and innovative ways so that at the "time" we ask children to complete their tasks they will be interested in completing them.

\section{d. Do not disturb friends when doing activities}

According to Martini Jamaris (2014), social behavior is defined as behavior carried out voluntarily that is able to benefit or please others without anticipation or external reward ". Forms of social behavior carried out in 
conjunction with good goals, such as helping by alleviating the burden of others, not disturbing friends while doing activities, helping the difficulties of others, and sharing with others who need it.

Description of the child's attitude does not interfere with his friend when doing activities is the child does not want to disturb his friend when his friend is doing activities. Field data collection gives the result that every informant with active parents in the school program, the informant is familiar with and understands class rules so that the informant never disturbs his friend while doing his activities even though sometimes the informant is also a bit ignorant in the sense of disturbing by teasing his friend but in a position when playing together his friends at the playground. The attitude shown by the informants agrees with Martini Jamaris (2014) in social behavior that is able to benefit others and not harm others. By not disturbing friends when doing activities is a form of behavior that is beneficial in society. And the informant has shown a good attitude by not disturbing friends when doing activities.

\section{e. Parent involvement}

Tirtayani (2014) involvement of parents is the participation or participation of the role of parents in the process of experiencing education in their children. As parents have full responsibility for the education of their children, especially training at home, because the first education received by children is education in the family, whereas when children enter school, the school institution only has the responsibility in directing, guiding and protecting children their children at school, and provide teaching and education to students in accordance with the curriculum used and pay attention to children's growth and development in accordance with their abilities.

Parent's involvement is a form of parent's attention to children. Either when the child is at school or when he is at home, with the involvement of parents with the existing program at school. Parents know more about the child's development at an early age in accordance with the stage of age. So that parents in providing care and services to children in accordance with the needs of children appropriate for their age. And child development will develop optimally. With parents knowing the kindergarten curriculum, taking part in parenting activities regularly, following the children's activity assistance program. indirectly benefited a lot of parents, added new insights and experiences.

\section{CONCLUSION}

Based on the results of some of the research data obtained, conclusions can be drawn about the involvement of parents in the children's emotional, social development program at Darusasalam Kindergarten Sidoarjo. Develops with the child's own will without coercion as well as the sincerity and awareness of parents. With experience and provide opportunities for children, in freedom of social exploration and habituation in the same direction when the child is at school and at home provided by the teacher, as well as involving parents in school and environmental programs.

\section{Recommendations}

1. To foster forms of emotional, social value abilities in obeying the class rules (activities, rules) of children, which must be done is to provide more opportunities for children to explore activities in interacting, socializing, so that stimulated children's emotional, social abilities, especially in terms of obeying the rules class (activities, rules), so that hopes for social-emotional development are able to develop optimally.

2. To implement the ability of social-emotional values in adhering to class rules (activities, rules) of children aged 5-6 years by involving parents in school programs in TK Darussalam Sidoarjo, it is necessary for the role of parents to change the habits in the family in supporting child development, especially the child's emotional, social development which will be sustainable in social life. This is very much needed in the child's emotional, social process. Support, appropriate stimulation, and opportunities to explore children can grow and develop children's emotional values.

\section{REFERENCES}

Peraturan Menteri Pendidikan dan Kebudayaan Republik Indonesia Nomor 137. (2014). Standar Nasional Pendidikan Anak Usia Dini. Jakarta: Permendikbud RI.

Papalia, Daniel (2014) Human Development - Psikologi Perkembangan Ed. 9, Bandung: Rosdakarya

Luh Ayu. T. (2014). Perkembangan Sosial Emosional Pada Anak Usia Dini. Yogyakarta: Graha Ilmu.

Creswell, John.W. (2015). Penelitian Kualitatif \& Desain Riset. Yogyakarta: Pustaka Pelajar

Sugiyono,.(2016). Metode Penelitian Kuantitatif, Kualitatif, dan R\&D. Bandung: Alfabeta.

Darmaji,. (2017). Metode Penelitian Pendidikan. Bandung: Alfabeta.

Milless. M.B. and Huberman (2014). Qualiatative data analisys. London: sage Publication.

Creswell, John.W. (2015). Penelitian Kualitatif \& Desain Riset. Yogyakarta: Pustaka Pelajar

Bachri, Bachtiar S. (2010). Meyakinkan Validitas Data Melalui Triangulasi pada Penelitian Kualitatif. Universitas Negri Surabaya. Surabaya.

Rimm Sylvia (2018) Mendidik dan Menerapkan Disiplin pada Anak Prasekolah (pola asuh anak masa kini). 
Jakarta: Gramedia.

Auerbach, S. (2017). Smart Play Smart Toys. (terjmhn) Septina Yuda. Jakarta: Busana Ilmu Populer.

Hurlock, E.B. (2015). Perkembangan Anak Jilid 2: Yogyakarta: Erlangga

Jamaris, M. (2014). Perkembangan dan Pengembagan Anak Usia Taman Kanak-Kanak; Pedoman Bagi Orang Tua dan Guru. Jakarta: Grasindo. 